\title{
North American Fungi
}

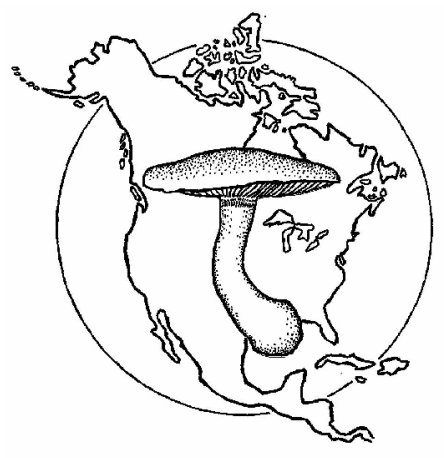

\author{
Volume 4, Number 5, Pages 1-4 \\ Published September 18, 2009 \\ Formerly Pacific Northwest Fungi
}

\section{Leightoniomyces phillipsii, a synnematous soil-dwelling hyphomycete new to North America}

\author{
Bruce McCune and Jeffrey Stone \\ Department of Botany and Plant Pathology, Oregon State University, \\ Corvallis, OR, U.S.A. 97331.
}

McCune, B. and J. Stone. 2009. Leightoniomyces phillipsii, a synnematous soil-dwelling hyphomycete new to North America. North American Fungi 4(5):1-4. doi: 10.2509/naf2009.004.005

Corresponding author: Bruce.McCune@science.oregonstate.edu. Accepted for publication September 10, 2009. http://pnwfungi.org Copyright (C) 2009 Pacific Northwest Fungi Project. All rights reserved.

\begin{abstract}
The synnematous hyphomycete Leightoniomyces phillipsii is reported as new to North America, based on a soil-dwelling specimen from Oregon, U.S.A. The species forms minute stalked spherical capitula resembling calicioid fungi.
\end{abstract}

Key words: anamorphic fungi, dematiaceous hyphomycetes, Leightoniomyces phillipsii, lichenicolous fungi, lichens, Oregon, Pacific Northwest, synnemata. 
Leightoniomyces phillipsii (Berk. \& Leight.)

D. Hawksw. \& B. Sutton

Periconia phillipsii Berk. \& Leight.

Doratomyces phillipsii (Berk. \& Leight.) F. J.

Morton \& G. Sm

Previously known from the Azores and the British Isles (Hawksworth 1977, Dennis et al. 1977, Morton and Smith 1983), Leightoniomyces phillipsii was recently found in western Oregon in the U.S.A. In the field, the species was visible only with a hand lens on nearly bare patches of soil in a matrix of bryophytes and lichens (including Cladonia fimbriata, C. furcata, C. verruculosa, Fuscopannaria coralloidea, Leptogium palmatum, Peltigera membranacea, $P$. praetextata, and $P$. venosa). The habitat was a damp, north-facing roadcut along a little-used dirt road. The roadcut was partly shaded by a canopy of Pseudotsuga menziesii, Arbutus menziesii, and Quercus garryana.

In at least some cases Leightoniomyces phillipsii has been found to be lichenicolous (Hawksworth 1977, 1983; on Steinia geophana and Thrombium epigaeum, both of which have Leptosira as the algal partner) and muscicolous (Berkeley and Broome 1875), but in this case we found no clear intimate association with lichens, algae, or bryophytes. We did see, however, when the material was fresh, a thin, amorphous, mucilaginous, and perhaps biological film covering the noncalcareous mineral soil. This film was apparent on the exposed patches of soil that were not colonized by bryophytes or lichens.

Because in at least some cases the species is lichenicolous, we suggest that it be included in future catalogs of lichenicolous fungi for North America.
Recently Muntañola-Cvetković and Gómez-Bolea (1998) reported a novel dematiaceous, synnematous, lichenicolous species, Arborillus llimonae growing on thalli of Diploschistes diacapsis on soil in central Spain. This fungus also produces verrucose, one-celled conidia but differs from $L$. phillipsii in having penicillate conidiophores with holoblastic-phialidic condiogenous cells, whereas conidiogenesis in $L$. phillipsii is holoblastic-annellidic (Hawksworth 1977).

Under the hand lens, L. phillipsii forms dark brown-black synnemata with globose heads about $0.10-0.15 \mathrm{~mm}$ in diameter, with short slender stalks, the stalk and capitulum together about $0.25 \mathrm{~mm}$ tall, resembling a tiny calicioid fungus (Figs. 1 and 2). Under the light microscope the conidia are distinctive: spherical, 12-13 $\mu \mathrm{m}$ in diameter, dark brown, coarsely verrucose, ornamented with raised roundish to polygonal knobs $3-5 \mu \mathrm{m}$ diam and ca. $3 \mu \mathrm{m}$ thick (Figs. 3 and 4), The conidia are dry, produced singly, adhering in short chains to form a compact, globose mass. Conidiogenous cells are annellidic with $2-4$ prominent scars, hyaline, rough-walled, crowded at the apices of the synnemeta, ovoid-ampulliform when young, becoming lageniform as the apex extends after several rounds of percurrent proliferation, $12-15$ $\mathrm{x} 5-7.5 \mu \mathrm{m}$. All parts of the fungus were K-. No teleomorph connection is known.

Specimen examined.- U.S.A.: Oregon, Douglas Co., Coast Range, $3 \mathrm{~km}$ SSE of town of Tenmile, $43.0895^{\circ} \mathrm{N} 123.5443^{\circ} \mathrm{W}, 445 \mathrm{~m}, 18$ April 2009, McCune 29952 (OSC). 


\section{Literature cited}

Berkeley, M. J. and C. E. Broome. 1875. Notices of British fungi (1402-1500). Annals and Magazine of Natural History 15(IV):28-41.

Dennis, R. W. G., D. A. Reid and B. Spooner. 1977. The fungi of the Azores. Kew Bulletin 32:85-136.

Hawksworth, D. L. 1977. Three new genera of lichenicolous fungi. Botanical Journal of the Linnean Society 75:195-209. doi: 10.1111/j.10958339.1977.tbo1484.x
Hawksworth, D. L. 1983. A key to the lichenforming, parasitic, parasymbiotic and saprophytic fungi occurring on lichens in the British Isles. Lichenologist 15:1-44. doi:10.1017/Soo24282983000031

Morton, F.J. and G. Smith, G. 1963. The genera Scopulariopsis Bainier, Microascus Zukal and Doratomyces Corda. Mycological Papers 86:1-96.

Muntañola-Cvetković, M. and A. Gómez-Bolea. 1998. Arborillus llimonae nov. gen. et sp., a synnematous lichenicolous hyphomycete. Mycotaxon 68: 145-155. 

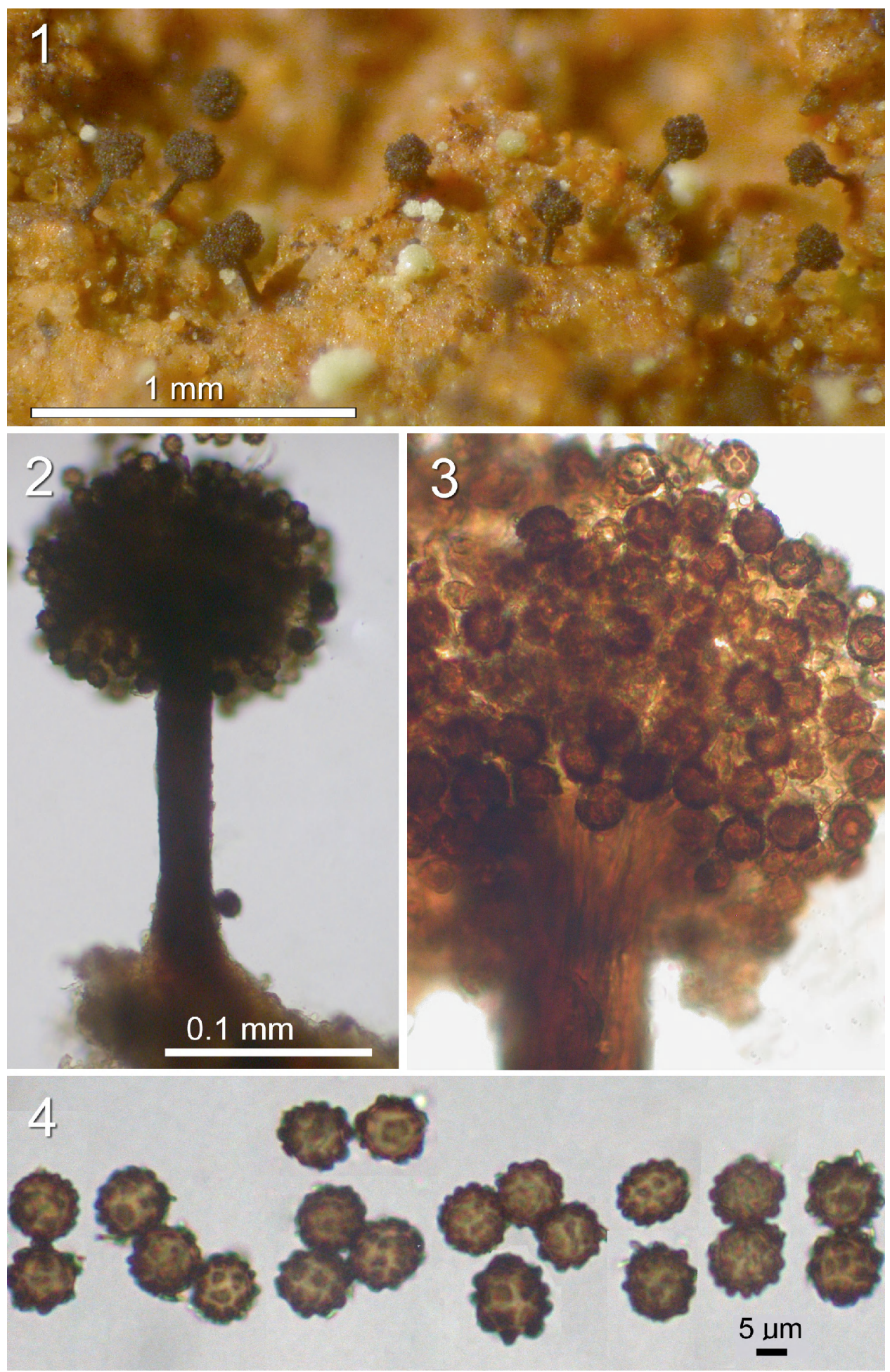

Figures 1-4. Leightoniomyces phillipsii (McCune 29952). 1. Synnemata on soil. 2. Synnema in water (compound microscope). 3. Capitulum gently squashed. 4. Conidia. 